\title{
Decision model for project bidding based on information diffusion
}

\author{
J.P. LI, W.X. CHEN, H.Y. YANG \& J.S. WANG
}

School of Civil Engineering and Architecture, Henan University of Technology, Zhengzhou, China

KEYWORD: bidding decision; information diffusion; probabilities estimation; profit expectations ABSTRACT: A decision model for construction enterprises is proposed in view of lack of data and uncertainty of quantitative relation existing in bidding decision. The ratio of bidding price of an opponent to the cost estimation of decision maker is regarded as random variable, and historical data of the ratio are diffused to monitoring points through the normal diffusion function. The probabilities and exceeding probabilities of monitoring points are estimated using the information diffusion results. Furthermore, the probability distributions of decision maker's bidding price being lower than opponent's are acquired, and profit expectations with different bidding prices of decision maker are figured out as the basis of bidding decision. The model is able to deal with bidding decision of single or multiple opponents. The case study illustrates the feasibility of this model. Finally, a new bidding decision method utilizing small sample data is presented in the paper.

\section{INTRODUCTION}

Under the condition of market economy, the construction enterprises have to undertake the task of project construction through bidding. However, with the fierce competition in the market, how to adopt a reasonable method to make scientific decision for bidding is a problem that decision makers encounter. The bidding price plays an important role in winning the bid.

Friedman(1956) proposed a bidding decision model based on probability distribution, this model regard the ratio of the bidding price of opponent to the cost estimation of decision maker as random variable, and then calculate the probability of the decision maker's bidding price being lower than the competitor's. The model provides an important reference for the later research. Gates(1967) presented another bidding decision model based on probability theory. Models of Friedman and Gates adopt probability analysis to determine the possibility of winning bid on the basis of the record of historical data, and made bidding decision. However, on the basis of same preconditions, the two models can draw different conclusions. Researchers had a long discussion about which of the two models being more reasonable, and no final conclusion has yet been reached on this matte (Crowley 2000).

The bidding decision models based on statistics and probability theory need to make use of a certain amount of data for decision analysis, and the amount of data has a great influence on the accuracy of the calculation results. However, it is difficult to obtain large amounts of data.

According to the principle of information diffusion, in the case of incomplete samples, reasonable diffusion functions that can improve the non - diffusion estimation exist(Huang 1997). The data used for bidding decision are often small sample, which are incomplete sample, and the traditional histogram method that is used to estimate the probability distribution function of random variables will lead to larger error. In this paper, information diffusion method is used to establish the information matrix, which can make full use of the information provided by the data. The information diffusion method that can improve the decision making process will provide a more scientific basis for decision making.

\section{INFORMATION DIFFUSION FUNCTION}

Definition 1(Huang 2005a) Let $X$ with universe $U$ be a sample and $V$ be a subset of $U$.A mapping from $X \times V$ to $[0,1]$

$\mu: X \times V \rightarrow[0,1]$

$(x, v) \rightarrow \mu(x, v), \quad \forall(x, v) \in X \times V$

is called an information diffusion of $X$ on $V$ if it is decreasing, i.e., 
$\forall x \in X, \quad \forall v^{\prime}, v^{\prime \prime} \in V$, if $\left\|v^{\prime}-x\right\| \leq\left\|v^{\prime \prime}-x\right\|$, then $\mu\left(x, v^{\prime}\right) \geq \mu\left(x, v^{\prime \prime}\right)$,

$\mu$ is called a diffusion function and $V$ is called a monitoring space. When $V=U$, we say that $\mu(x, v)$ is sufficient.

The information diffusion function can be used to diffuse the information from the sample to the monitoring point.

The normal information diffusion function is as follows (Huang 2005a).

$\mu(x, u)=\frac{1}{h \sqrt{2 \pi}} \exp \left[-\frac{(x-u)^{2}}{2 h^{2}}\right]$

where, $h$ is diffusion coefficient according to the value of Table 1.

Table 1. Values of diffusion coefficient

\begin{tabular}{cccccc} 
& \multicolumn{5}{c}{ Table 1. Values of diffusion coefficient } \\
\cline { 2 - 6 } & Sample size & 5 & 6 & 7 & 8 \\
\cline { 2 - 6 } & Calculation & 0.8146 & $0.5690 l$ & 0.456 & 0.3860 \\
formula of $h$ & $l$ & & $0 l$ & $l$ \\
\hline \hline Sample size & 9 & 10 & $\geq 11$ \\
\hline note: $l=\max \left\{x_{i}\right\}-\min \left\{x_{i}\right\}$ & $\begin{array}{l}\text { Calculation } \\
\text { formula of } h\end{array}$ & 0.3362 & 0.29861 & $2.6851 l /(n-1)$ \\
\cline { 2 - 5 } & $x_{i}$ is one dimensional data, $n$ is sample size
\end{tabular}

\section{BIDDING DECISION MODEL}

\section{Calculation of winning bid probability \\ Situation with an opponent}

Let

$$
R^{c}=\frac{x}{C_{e}}
$$

where, $x$ is bidding price of opponent; $C_{e}$ is the estimation of cost made by decision maker.

$R^{c}$ is a random variable, and the probability of bidding price of decision maker being lower than that of the opponent is as follows(Friedman 1956)

$P\left(R^{c} \geq \frac{y_{0}}{C_{e}}\right)=\int_{y_{0} / C_{e}}^{\infty} f_{R^{c}}(r) d r$

where, $f_{R^{c}}(r)$ is the probability distribution density function of $R^{c}$.

Let

$r^{b}=\frac{y_{b}}{C_{e}}$

where, $y_{b}$ is the bidding price of decision maker.

Let us suppose that decision maker has encountered the opponent several times, and the decision maker holds record of $R^{c}$ that is $\left\{r_{1}^{c}, r_{2}^{c}, \mathrm{~L}, r_{N}^{c}\right\}$.

Let monitoring points of $R^{c}$ be $U=\left\{u_{1}, u_{2}, \ldots, u_{m}\right\}$, then the information provided by $r_{i}^{c}$ can be diffused to the monitoring point $u_{j}$.According to formula (1), the diffusion formula is as below

$f_{i}\left(u_{j}\right)=\frac{1}{h \sqrt{2 \pi}} \exp \left[-\frac{\left(r_{i}^{c}-u_{j}\right)^{2}}{2 h^{2}}\right]$

According to Huang (2005b),there are formulas as follows

$C_{i}=\sum_{j=1}^{m} f_{i}\left(u_{j}\right)$ 


$$
\begin{aligned}
& q\left(u_{j}\right)=\sum_{i=1}^{N} \frac{f_{i}\left(u_{j}\right)}{C_{i}} \\
& Q=\sum_{j=1}^{m} q\left(u_{j}\right) \\
& p\left(u_{j}\right)=\frac{q\left(u_{j}\right)}{Q}
\end{aligned}
$$

where, $p\left(u_{j}\right)$ is the probability estimation of monitoring point $u_{j}$.

Exceeding probability of $u_{j}$ can be figured out as follows

$$
P\left(u_{j}\right)=\sum_{k=j}^{m} p\left(u_{j}\right)
$$

If

$$
r_{j}^{b}=u_{j}-\Delta
$$

where, $\Delta=\frac{u_{i}-u_{i-1}}{2}$.

Then the bidding price of decision maker is $y_{j}$.

$y_{j}=r_{j}^{b} \cdot C_{e}^{n}$

where, $C_{e}^{n}$ is the cost estimation made by decision maker for the intended bidding project.

Evidently, when $y_{j}$ is adopted as the bidding price by decision maker, the probability of $y_{j}$ being lower than bidding price of opponent is $P\left(u_{j}\right)$.

\section{Situation with multiple opponents}

In the situation with multiple opponents, it is necessary for the decision maker winning the bidding that the decision maker's bidding price is lower than all opponents'. Bidding of each opponent is independent event, and if there are $C$ opponents, probability of decision maker winning all opponents can be calculated, then the probability of decision maker's bidding price being lower than all opponents' is as follows.

$$
P\left(u_{j}\right)=\prod_{k=1}^{C} P_{k}\left(u_{j}\right)
$$

where, $P_{k}\left(u_{j}\right)$ is the probability of bidding price $y_{j}$ of decision maker being lower than that of the opponent $k$.

\section{Bidding price decision making}

If decision maker's bidding price is $y_{j}$, profit expectation value of decision maker is

$$
M\left(y_{j}\right)=\left(y_{j}-C_{e}^{n}\right) \cdot P\left(u_{j}\right)-C_{b}\left[1-P\left(u_{j}\right)\right]
$$

where, $C_{b}$ is the decision maker's cost on bidding.

Then, the optimal bidding of decision maker is $y_{p}$

$$
\text { s.t. } \quad M\left(y_{p}\right)=\max _{j}\left(M\left(y_{j}\right)\right)
$$

\section{CASE STUDY}

\section{Background}

A construction enterprise was going to bid for a project. It was known that there were three opponents $\mathrm{A}, \mathrm{B}$ and $\mathrm{C}$ intending to bid for the project. The decision maker had met the enterprises several times, and the bidding records are follows. 
Table 2. Data of bidder A

\begin{tabular}{cccccc}
\hline No. & 1 & 2 & 3 & 4 & 5 \\
\hline$r^{c}$ & 1.030 & 1.100 & 1.070 & 1.050 & 1.130 \\
\hline No. & 6 & 7 & 8 & 9 & 10 \\
\hline$r^{c}$ & 1.120 & 1.100 & 1.140 & 1.140 & 1.150 \\
\hline
\end{tabular}

Table 3. Data of bidder B

\begin{tabular}{ccccc}
\hline No. & 1 & 2 & 3 & 4 \\
\hline$r^{c}$ & 1.050 & 1.060 & 1.030 & 1.140 \\
\hline \hline No. & 5 & 6 & 7 & 8 \\
\hline$r^{c}$ & 1.030 & 1.130 & 1.130 & 1.120 \\
\hline
\end{tabular}

Table 4. Data of bidder C

\begin{tabular}{ccccc}
\hline No. & 1 & 2 & 3 & 4 \\
\hline$r^{c}$ & 1.100 & 1.020 & 1.050 & 1.020 \\
\hline \hline No. & 5 & 6 & 7 & 8 \\
\hline$r^{c}$ & 1.030 & 1.050 & 1.150 & 1.040 \\
\hline
\end{tabular}

In the above tables, $r^{c}$ is the observed value of $R^{c}, R^{c}$ is defined by formula (2).

The decision maker estimated the cost of this project to be 53.62 million yuan.

\section{Probability of winning the bid}

The monitoring space $r^{c}$ was chosen as $U=\left\{u_{1}, u_{2}, u_{3}, u_{4}, u_{5}, u_{6}, u_{7}, u_{8}, u_{9}, u_{10}\right\}=\{1.020,1.034$, $1.049,1.063,1.078,1.092,1.107,1.121,1.136,1.150\}$. According to formula (5), the information diffusion value matrix of A's data to the monitoring points was obtained. Probabilities of monitoring points were figured out on the basis of formula (9), exceeding probabilities of monitoring points were calculated according to formula (10), they are listed below.

Table 5. Estimation of monitoring points probabilities and exceeding probabilities of opponent A

\begin{tabular}{lccccc}
\hline $\begin{array}{l}\text { Monitoring } \\
\text { point }\end{array}$ & $u_{1}$ & $u_{2}$ & $u_{3}$ & $u_{4}$ & $u_{5}$ \\
\hline Probability & 0.04 & 0.06 & 0.07 & 0.08 & 0.09 \\
& 6 & 0 & 3 & 5 & 9 \\
\hline Exceeding & 1.00 & 0.95 & 0.89 & 0.82 & 0.73 \\
probability & 0 & 4 & 4 & 2 & 6 \\
\hline \hline Monitoring & $u_{6}$ & $u_{7}$ & $u_{8}$ & $u_{9}$ & $u_{10}$ \\
point & 0.11 & 0.13 & 0.13 & 0.13 & 0.11 \\
Probability & 5 & 0 & 8 & 5 & 9 \\
\hline Exceeding & 0.63 & 0.52 & 0.39 & 0.25 & 0.11 \\
probability & 7 & 2 & 2 & 4 & 9 \\
\hline
\end{tabular}

According to formula (12), probability distributions of decision maker's bidding price being lower than A's were figured out. 
Table 6. Probability distributions of decision maker's bidding price being lower than A's

\begin{tabular}{lccccc}
\hline $\begin{array}{l}\text { Decision maker' } \\
\text { s bidding }\end{array}$ & $\begin{array}{c}543 \\
\text { price(ten }\end{array}$ & $\begin{array}{c}550 \\
\text { thousand yuan) }\end{array}$ & $\begin{array}{c}558 \\
5\end{array}$ & $\begin{array}{c}566 \\
2\end{array}$ & $\begin{array}{c}574 \\
0\end{array}$ \\
\hline $\begin{array}{l}\text { Probability of } \\
\text { being lower than }\end{array}$ & $\begin{array}{c}1.00 \\
0\end{array}$ & $\begin{array}{c}0.95 \\
4\end{array}$ & $\begin{array}{c}0.89 \\
4\end{array}$ & $\begin{array}{c}0.82 \\
2\end{array}$ & $\begin{array}{c}0.73 \\
6\end{array}$ \\
A & & & & & \\
\hline $\begin{array}{l}\text { Decision maker' } \\
\text { s bidding }\end{array}$ & 581 & 589 & 597 & $\begin{array}{c}605 \\
0\end{array}$ & $\begin{array}{c}612 \\
7\end{array}$ \\
$\begin{array}{l}\text { price(ten } \\
\text { thousand yuan) }\end{array}$ & 7 & 5 & 2 & 0 & \\
\hline $\begin{array}{l}\text { Probability of } \\
\text { being lower than }\end{array}$ & 0.63 & 0.52 & 0.39 & 0.25 & 0.11 \\
A & 7 & 2 & 2 & 4 & 9 \\
\hline
\end{tabular}

Similarly, probabilities and exceeding probabilities of monitoring points according to data of bidder $\mathrm{B}$ are listed below.

Table 7. Estimation of monitoring points probabilities and exceeding probabilities of opponent B

\begin{tabular}{lccccc}
\hline $\begin{array}{l}\text { Monitoring } \\
\text { point }\end{array}$ & $u_{1}$ & $u_{2}$ & $u_{3}$ & $u_{4}$ & $u_{5}$ \\
\hline Probability & $\begin{array}{c}0.06 \\
6\end{array}$ & $\begin{array}{c}0.07 \\
7\end{array}$ & $\begin{array}{c}0.08 \\
3\end{array}$ & $\begin{array}{c}0.08 \\
8\end{array}$ & $\begin{array}{c}0.09 \\
4\end{array}$ \\
\hline $\begin{array}{l}\text { Exceeding } \\
\text { probability }\end{array}$ & $\begin{array}{c}1.00 \\
0\end{array}$ & $\begin{array}{c}0.93 \\
4\end{array}$ & $\begin{array}{c}0.85 \\
7\end{array}$ & $\begin{array}{c}0.77 \\
4\end{array}$ & $\begin{array}{c}0.68 \\
6\end{array}$ \\
\hline \hline $\begin{array}{l}\text { Monitoring } \\
\text { point }\end{array}$ & $u_{6}$ & $u_{7}$ & $u_{8}$ & $u_{9}$ & $u_{10}$ \\
\hline Probability & $\begin{array}{c}0.10 \\
3\end{array}$ & $\begin{array}{c}0.11 \\
5\end{array}$ & $\begin{array}{c}0.12 \\
6\end{array}$ & $\begin{array}{c}0.12 \\
9\end{array}$ & 0.12 \\
\hline $\begin{array}{l}\text { Exceeding } \\
\text { probability }\end{array}$ & $\begin{array}{c}0.59 \\
3\end{array}$ & $\begin{array}{c}0.49 \\
0\end{array}$ & $\begin{array}{c}0.37 \\
5\end{array}$ & $\begin{array}{c}0.24 \\
9\end{array}$ & $\begin{array}{c}0.12 \\
0\end{array}$ \\
\hline
\end{tabular}

The probability distributions of decision maker's bidding price being lower than B's were obtained.

Table 8. Probability distributions of decision maker's bidding price being lower than B's

\begin{tabular}{lccccc}
\hline $\begin{array}{l}\text { Decision } \\
\text { maker' s }\end{array}$ & 543 & 550 & 558 & 566 & 574 \\
bidding & 0 & 8 & 5 & 2 & 0 \\
$\begin{array}{l}\text { price(ten } \\
\text { thousand yuan) }\end{array}$ & & & & & \\
\hline $\begin{array}{l}\text { Probability of } \\
\text { being lower } \\
\text { than B }\end{array}$ & 1.00 & 0.93 & 0.85 & 0.77 & 0.68 \\
\hline \hline $\begin{array}{l}\text { Decision } \\
\text { maker' s }\end{array}$ & 0 & 4 & 7 & 4 & 6 \\
$\begin{array}{l}\text { bidding } \\
\text { price(ten } \\
\text { thousand yuan) }\end{array}$ & 581 & 589 & 597 & 605 & 612 \\
\hline $\begin{array}{l}\text { Probability of } \\
\text { being lower }\end{array}$ & 0.59 & 0.49 & 0.37 & 0.24 & 0.12 \\
than B & 3 & 0 & 5 & 9 & 0 \\
\hline
\end{tabular}


Probabilities and exceeding probabilities of monitoring points according to data of bidder $\mathrm{C}$ are listed below.

Table 9. Estimation of monitoring points probabilities and exceeding probabilities of opponent $\mathrm{C}$

\begin{tabular}{lccccc}
\hline $\begin{array}{l}\text { Monitoring } \\
\text { point }\end{array}$ & $u_{1}$ & $u_{2}$ & $u_{3}$ & $u_{4}$ & $u_{5}$ \\
\hline Probability & 0.10 & 0.11 & 0.11 & 0.10 & 0.10 \\
& 5 & 1 & 1 & 6 & 0 \\
\hline $\begin{array}{l}\text { Exceeding } \\
\text { probability }\end{array}$ & $\begin{array}{c}1.00 \\
0\end{array}$ & $\begin{array}{c}0.89 \\
5\end{array}$ & $\begin{array}{c}0.78 \\
4\end{array}$ & $\begin{array}{c}0.67 \\
3\end{array}$ & $\begin{array}{c}0.56 \\
7\end{array}$ \\
\hline \hline Monitoring & $u_{6}$ & $u_{7}$ & $u_{8}$ & $u_{9}$ & $u_{10}$ \\
point & 0.09 & 0.09 & 0.09 & 0.09 & 0.08 \\
Probability & 6 & 4 & 5 & 4 & 8 \\
\hline Exceeding & 0.46 & 0.37 & 0.27 & 0.18 & 0.08 \\
probability & 7 & 1 & 7 & 2 & 8 \\
\hline
\end{tabular}

The probability distributions of decision maker's bidding price being lower than C's were obtained.

Table 10 Probability distributions of decision maker's bidding price being lower than C's

\begin{tabular}{|c|c|c|c|c|c|}
\hline $\begin{array}{l}\text { Decision maker' } \\
\text { s bidding } \\
\text { price(ten } \\
\text { thousand yuan) }\end{array}$ & $\begin{array}{c}543 \\
0\end{array}$ & $\begin{array}{c}550 \\
8\end{array}$ & $\begin{array}{c}558 \\
5\end{array}$ & $\begin{array}{c}566 \\
2\end{array}$ & $\begin{array}{c}574 \\
0\end{array}$ \\
\hline $\begin{array}{l}\text { Probability of } \\
\text { being lower } \\
\text { than C } \\
\end{array}$ & $\begin{array}{c}1.00 \\
0\end{array}$ & $\begin{array}{c}0.89 \\
5\end{array}$ & $\begin{array}{c}0.78 \\
4\end{array}$ & $\begin{array}{c}0.67 \\
3\end{array}$ & $\begin{array}{c}0.56 \\
7\end{array}$ \\
\hline $\begin{array}{l}\text { Decision maker' } \\
\text { s bidding } \\
\text { price(ten } \\
\text { thousand yuan) }\end{array}$ & $\begin{array}{c}581 \\
7\end{array}$ & $\begin{array}{c}589 \\
5\end{array}$ & $\begin{array}{c}597 \\
2\end{array}$ & $\begin{array}{c}605 \\
0\end{array}$ & $\begin{array}{c}612 \\
7\end{array}$ \\
\hline $\begin{array}{l}\text { Probability of } \\
\text { being lower } \\
\text { than C }\end{array}$ & $\begin{array}{c}0.46 \\
7\end{array}$ & $\begin{array}{c}0.37 \\
1\end{array}$ & $\begin{array}{c}0.27 \\
7\end{array}$ & $\begin{array}{c}0.18 \\
2\end{array}$ & $\begin{array}{c}0.08 \\
8\end{array}$ \\
\hline
\end{tabular}

The probability distributions of decision maker's bidding price being lower than all opponents' were worked out on the basis of formula (13). 
Table 11. Probability distributions of decision maker's bidding price being lower than all opponents

\begin{tabular}{|c|c|c|c|c|c|}
\hline $\begin{array}{l}\text { Decision } \\
\text { maker' s } \\
\text { bidding } \\
\text { price(ten } \\
\text { thousand } \\
\text { yuan) }\end{array}$ & $\begin{array}{c}543 \\
0\end{array}$ & $\begin{array}{c}550 \\
8\end{array}$ & $\begin{array}{c}558 \\
5\end{array}$ & $\begin{array}{c}566 \\
2\end{array}$ & $\begin{array}{c}574 \\
0\end{array}$ \\
\hline $\begin{array}{l}\text { Probability of } \\
\text { being lower } \\
\text { than all } \\
\text { opponents }\end{array}$ & $\begin{array}{c}1.00 \\
0\end{array}$ & $\begin{array}{c}0.79 \\
8\end{array}$ & $\begin{array}{c}0.60 \\
1\end{array}$ & $\begin{array}{c}0.42 \\
8\end{array}$ & $\begin{array}{c}0.28 \\
6\end{array}$ \\
\hline $\begin{array}{l}\text { Decision } \\
\text { maker' s } \\
\text { bidding } \\
\text { price(ten } \\
\text { thousand } \\
\text { yuan) }\end{array}$ & $\begin{array}{c}581 \\
7\end{array}$ & $\begin{array}{c}589 \\
5\end{array}$ & $\begin{array}{c}597 \\
2\end{array}$ & $\begin{array}{c}605 \\
0\end{array}$ & $\begin{array}{c}612 \\
7\end{array}$ \\
\hline $\begin{array}{l}\text { Probability of } \\
\text { being lower } \\
\text { than all } \\
\text { opponents }\end{array}$ & $\begin{array}{c}0.17 \\
6\end{array}$ & $\begin{array}{c}0.09 \\
5\end{array}$ & $\begin{array}{c}0.04 \\
1\end{array}$ & $\begin{array}{c}0.01 \\
2\end{array}$ & $\begin{array}{c}0.00 \\
1\end{array}$ \\
\hline
\end{tabular}

\section{Decision making of bidding price}

Bidding cost being ignored, bidding profit expectation values of decision maker were obtained in accordance with formula (14).

Table 12. Bidding profit expectation values of decision maker

\begin{tabular}{|c|c|c|c|c|c|}
\hline $\begin{array}{l}\text { Decision } \\
\text { maker' s } \\
\text { bidding } \\
\text { price(ten } \\
\text { thousand yuan) }\end{array}$ & $\begin{array}{c}543 \\
0\end{array}$ & $\begin{array}{c}550 \\
8\end{array}$ & $\begin{array}{c}558 \\
5\end{array}$ & $\begin{array}{c}566 \\
2\end{array}$ & $\begin{array}{c}574 \\
0\end{array}$ \\
\hline $\begin{array}{l}\text { Profit } \\
\text { expectation } \\
\text { values(ten } \\
\text { thousand yuan) }\end{array}$ & 68.5 & $\begin{array}{c}116 . \\
4\end{array}$ & $\begin{array}{c}134 . \\
3\end{array}$ & $\begin{array}{c}128 . \\
8\end{array}$ & $\begin{array}{c}108 . \\
3\end{array}$ \\
\hline $\begin{array}{l}\text { Decision } \\
\text { maker's } \\
\text { bidding } \\
\text { price(ten } \\
\text { thousand yuan) }\end{array}$ & $\begin{array}{c}581 \\
7\end{array}$ & $\begin{array}{c}589 \\
5\end{array}$ & $\begin{array}{c}597 \\
2\end{array}$ & $\begin{array}{c}605 \\
0\end{array}$ & $\begin{array}{c}612 \\
7\end{array}$ \\
\hline $\begin{array}{l}\text { Profit } \\
\text { expectation } \\
\text { values(ten } \\
\text { thousand yuan) }\end{array}$ & 80.3 & 50.6 & 24.9 & 7.9 & 0.9 \\
\hline
\end{tabular}

Obviously, the maximum bidding profit expectation value is 134.3 ten thousand yuan with the bidding price 5585 ten thousand yuan, and then the optimal bidding price is 5585 ten thousand yuan. 


\section{CONCLUSIONS}

As a result of business competition, it is very difficult to get the data of competitors, the decision maker has to make full use of less data to make decision analysis. Because of the lack of data, the bidding decision models based on probability theory whose basis is the law of large numbers are of obvious limitation. Information diffusion theory has been proved to be a good method for small sample data analysis (Huang 2005a).In this paper, the information diffusion theory is applied to the bidding decision making, and the decision model is put forward to make full use of the information provided by the data, and the decision result depends on objective data. The model mentioned in this paper has some practical value.

\section{REFERENCES}

1) Crowley, L. G. 2000.Friedman and Gates-Another Look . Journal of Construction Engineering and Management, 126(4): 306-312.

2) Friedman, L. A. 1956.competitive-bidding strategy. Operations Research, ,4(1): 104-112.

3) Gates, M. 1967.Bidding strategies and probabilities. Journal of the Construction Division, 93(CO1): 75-107.

4) Huang, C. F. 1997.Principle of information diffusion. Fuzzy Sets and Systems, 91(1): 69-90.

5) Huang, C. F, 2005a. Moraga C. Extracting fuzzy if-then rules by using the information matrix technique. Journal of Computer and System Sciences, 70(1): 26-52.

6) Huang, C. F. 2005b .Risk assessment of natural disasters: theory and practice . Beijing: Science Press. 